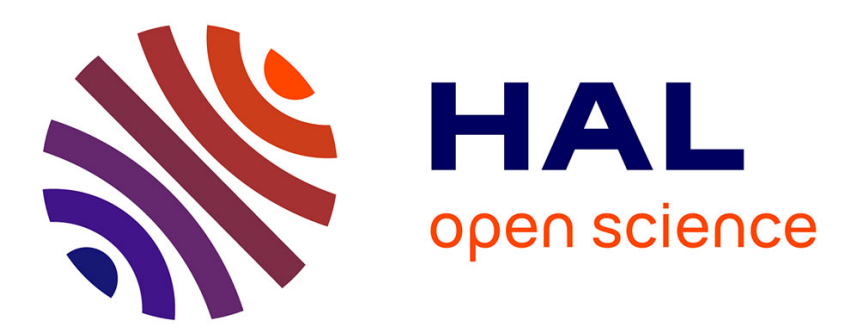

\title{
Selective hydrogenation of alkenes using ZIF-67 shell membrane deposited on platinum/alumina core catalyst
}

Feng Jiao, Hailing Guo, Lei Zhao, Junjuan Liu, Yongming Chai, Svetlana Mintova, Chenguang Liu

\section{- To cite this version:}

Feng Jiao, Hailing Guo, Lei Zhao, Junjuan Liu, Yongming Chai, et al.. Selective hydrogenation of alkenes using ZIF-67 shell membrane deposited on platinum/alumina core catalyst. Microporous and Mesoporous Materials, 2019, 276, pp.98-106. 10.1016/j.micromeso.2018.09.026 . hal-02410035

\section{HAL Id: hal-02410035 \\ https://hal.science/hal-02410035}

Submitted on 27 Nov 2020

HAL is a multi-disciplinary open access archive for the deposit and dissemination of scientific research documents, whether they are published or not. The documents may come from teaching and research institutions in France or abroad, or from public or private research centers.
L'archive ouverte pluridisciplinaire HAL, est destinée au dépôt et à la diffusion de documents scientifiques de niveau recherche, publiés ou non, émanant des établissements d'enseignement et de recherche français ou étrangers, des laboratoires publics ou privés. 


\section{Selective Hydrogenation of Alkenes using ZIF-67 Shell}

\section{Membrane Deposited on Platinum/Alumina Core Catalyst}

Feng Jiao $^{\mathrm{a} \triangle}$, Hailing Guo ${ }^{\mathrm{a} *}{ }^{\triangle}$, Lei Zhao ${ }^{\mathrm{a}}$, Junjuan Liu ${ }^{\mathrm{a}}$ Yongming Chai ${ }^{\mathrm{a}}$, Svetlana Mintova $^{\mathrm{a}, \mathrm{b}}$, Chenguang Liu ${ }^{\mathrm{a}}$

a State Key Laboratory of Heavy Oil Processing, Key Laboratory of Catalysis, China National Petroleum Corp. (CNPC) China University of Petroleum (East China), Qingdao 266555, P. R. China.

${ }^{\mathrm{b}}$ Laboratoire Catalyse et Spectrochimie (LCS), Normandie University, ENSICAEN, UNICAEN, CNRS, 6 boulevard du Marechal Juin, 14050 Caen, France

$\Delta$ : These authors contributed equally to this work

E-mail: guohl@upc.edu.cn

\section{Keywords}

Core-shell catalyst; Selective hydrogenation; Sulfur-tolerant material. 


\begin{abstract}
:
A new core-shell catalyst ( $\left.\mathrm{Pt} / \mathrm{Al}_{2} \mathrm{O}_{3} @ \mathrm{ZIF}-67\right)$ for selective hydrogenation of alkenes was prepared by coating platinum/alumina $\left(\mathrm{Pt}_{\mathrm{Al}} \mathrm{O}_{3}\right)$ core with $\mathrm{ZIF}-67$ shell membrane. The aperture size of the ZIF-67 $(0.34 \mathrm{~nm})$ is sufficiently small thus exclude large reactant and toxic substances thereby preventing deactivation and leakage of noble metal $(\mathrm{Pt})$ incorporated in the core. The $\mathrm{Pt} / \mathrm{Al}_{2} \mathrm{O}_{3} @ \mathrm{ZIF}-67$ core-shell catalyst exhibited exceptional size-selective catalytic properties in hydrogenation reaction. The core-shell catalyst is selective toward alkenes (hexene $0.17 \mathrm{~nm}$, cyclohexene $0.42 \mathrm{~nm}$, cyclooctene $0.55 \mathrm{~nm}$ ), and showed excellent resistance to sulfur poisoning. The $\mathrm{Pt} / \mathrm{Al}_{2} \mathrm{O}_{3} @ \mathrm{ZIF}-67$ core- -shell catalyst displayed outstanding stability and maintain high activity and selectivity after four subsequent working cycles. The conversion of hexene reached $100 \%$ at $200{ }^{\circ} \mathrm{C}$, while the conversion of cyclohexene and cyclooctene was $40 \%$ and $10 \%$, respectively.
\end{abstract}

\title{
1. Introduction
}

Precious metal nanoparticles supported on various kinds of porous materials exhibit excellent catalytic performance [1-6] in hydrogenations [7-9]. However, these supported noble metal catalysts often suffered from serious problems such as leaching, sintering and poisoning from toxic substances [10-12]. Attempts have been made to overcome these problems [13-17]. Encapsulation of noble metals within porous materials can prevent their contact with toxic substances and also protect them from sintering, while concurrently allowing active sites to selectively react on the basis of molecular sieve effect. Goel et al. reported the synthesis of metal clusters encapsulated within small-pore (SOD, GIS, ANA) zeolite [18]. Otto et al. also described Au clusters encapsulated within LTA zeolite and applied in oxidative dehydrogenation (ODH) of 
alkanols [19]. However, the confinement of noble metal clusters within small-pore zeolites $(<0.5 \mathrm{~nm}$ apertures $)$ is still not trivial. The high loading of noble metals in zeolites leads to partial leaching and deposition on the external surface of the zeolite crystals, which then inevitably become inactive by the presence of toxic substances. Even more, the high loading of noble metals encapsulated in zeolite will cause the collapse of the zeolite framework, which is related with the zeolite structure used [20, 21]. Therefore, manufacture of core--shell catalysts is considered as a promising route toward solving these problems [22-24]. Generally, core-shell catalysts are prepared by catalytically active noble metal cores covered with porous shells, which not only protect the noble metal nanoparticles from being poisoned, but also improve their catalytic properties, activity and selectivity [25-27].

The property of shell materials is vital for core- shell catalysts. So far, many types of shell materials with excellent performance have been demonstrated [28-31]. Recently, Metal-organic frameworks (MOFs) have been proven to be promising candidates as shell materials due to their controllable properties, uniform pore size, well-defined pore structures, and excellent chemical stability [32, 33]. Zeolite imidazolate frameworks (ZIFs) are a subfamily of MOFs combining their structural advantages (framework diversity) with remarkably high thermal and chemical stabilities [34, 35]. ZIFs specific applications in core-shell catalysts, however, depend greatly on the ability to control the size and shape of individual ZIFs crystallites as well as their assembly on various supporting surfaces. The nanostructure Pd@ZIF-8 yolkshell was designed for gas-phase heterogeneous catalysis [36]. The silica-ZIF-8 with tunable ordered meso-microporosity was synthesized for shape selection [37]. Good performance of these core-shell catalysts was demonstrated, however, there are many challenges related with the preparation of the core-shell materials and specifically with 
their use in catalysis: (1) Large-scale preparation and regulation of continuous compact ultrathin shell. (2) Avoiding aggregation of the nanoparticles during the formation of shell. Thus, further study is required to solve the above problems.

In this work, we report the preparation of a new core-shell Pt/ $/ \mathrm{Al}_{2} \mathrm{O}_{3} @ \mathrm{ZIF}-67$ catalyst. The metal (platinum) particles were loaded in the $\mathrm{Al}_{2} \mathrm{O}_{3}$ core, and the $\mathrm{ZIF}-67$ was deposited as a shell and used as a selective and protective layer (Scheme 1). The porous $\mathrm{Al}_{2} \mathrm{O}_{3}$ was selected as a core to support the $\mathrm{Pt}$ incorporation in order to avoid further aggregation, and increase dispersion degree, uniformity and catalytic efficiency. The ZIF-67 shell membrane grown on the outer surface of the $\mathrm{Pt} / \mathrm{Al}_{2} \mathrm{O}_{3}$ core has two main functions: (1) acts as shape-selective molecular sieve that selectively allows small-sized reactants to pass freely through the shell and react with the active core, and to hinder the participation reaction of large-sized reactants, simultaneously, and (2) acts as a barrier of toxic substances and protects the active Pt core from poisoning.

\section{Experiment}

\subsection{Chemicals}

$\alpha-\mathrm{Al}_{2} \mathrm{O}_{3}$ pellets (Sasol, 1-1.3 mm, $24.3 \mathrm{~m}^{2} \cdot \mathrm{g}^{-1}$ ), chloroplatinic acid hexa-hydrate $\left(\mathrm{H}_{2} \mathrm{PtCl}_{6} \cdot 6 \mathrm{H}_{2} \mathrm{O}, 37 \%\right)$, cobalt acetate $\left(\mathrm{Co}\left(\mathrm{CH}_{3} \mathrm{CO}_{2}\right)_{2} \cdot 4 \mathrm{H}_{2} \mathrm{O}, 99 \%\right)$, 2-methylimidazole $\left(\mathrm{C}_{4} \mathrm{H}_{6} \mathrm{~N}_{2}, 98 \%\right)$, tri-ethylamine $\left(\left(\mathrm{C}_{2} \mathrm{H}_{5}\right)_{3} \mathrm{~N}, 99 \%\right)$, urea $\left(\mathrm{CO}\left(\mathrm{NH}_{2}\right)_{2}, 99 \%\right)$, hexene $\left(\mathrm{C}_{6} \mathrm{H}_{12}, 99 \%\right)$, cyclohexene $\left(\mathrm{C}_{6} \mathrm{H}_{10}, 99 \%\right)$, cyclooctene $\left(\mathrm{C}_{8} \mathrm{H}_{14}, 95 \%\right)$, heptane $\left(\mathrm{C}_{7} \mathrm{H}_{16}\right.$, $98 \%)$, dibenzothiophene $\left(\mathrm{C}_{12} \mathrm{H}_{8} \mathrm{~S}, 99 \%\right)$, and ethanol $\left(\mathrm{C}_{2} \mathrm{H}_{6} \mathrm{O}, 99 \%\right)$ were purchased from Sinopharm Chemical Reagent Co., Ltd. All reagents and solvents were used as received without further treatment. Deionized water generated by a Barnstead water system was used for all syntheses.

\subsection{Preparation of $\mathrm{Pt}_{/} \mathrm{Al}_{2} \mathrm{O}_{3}$ core}


The $\mathrm{Pt} / \mathrm{Al}_{2} \mathrm{O}_{3}$ core catalyst was prepared by depositing an aqueous solution of $\mathrm{H}_{2} \mathrm{PtCl}_{6} \cdot 6 \mathrm{H}_{2} \mathrm{O}$ on $\alpha-\mathrm{Al}_{2} \mathrm{O}_{3}$ pellets. $2.1 \mathrm{ml}$ of a solution of $1 \mathrm{~g} \mathrm{H}_{2} \mathrm{PtCl}_{6} \cdot 6 \mathrm{H}_{2} \mathrm{O}$ dissolved in $20 \mathrm{ml}$ deionized water, $100 \mathrm{ml}$ deionized water, and $3 \mathrm{~g} \mathrm{\alpha}-\mathrm{Al}_{2} \mathrm{O}_{3}$ were added to a flask under continuous stirring at $80{ }^{\circ} \mathrm{C}$ for $10 \mathrm{~h}$. After $1 \mathrm{~h}, 1.2 \mathrm{~g}$ urea was added to the solution, the sample was dried at $80{ }^{\circ} \mathrm{C}$ for $12 \mathrm{~h}$, and then calcined in air at $500{ }^{\circ} \mathrm{C}$ for $4 \mathrm{~h}$. The platinum loading on the $\alpha-\mathrm{Al}_{2} \mathrm{O}_{3}$ determined by ICP-AES was $0.52 \mathrm{wt} . \%$. The dispersion of platinum estimated by $\mathrm{H}_{2}$ chemisorption was $51 \%$.

\subsection{Preparation of $\mathrm{Pt}_{\mathrm{A}} \mathrm{Al}_{2} \mathrm{O}_{3} @ \mathrm{ZIF}-67$ core-shell catalyst}

The surface of the $\mathrm{Pt} / \mathrm{Al}_{2} \mathrm{O}_{3}$ core catalyst was treated with a $60 \mathrm{wt} . \%$ tri-ethylamine solution at $50{ }^{\circ} \mathrm{C}$ for $2 \mathrm{~h}$, washed three times with ethanol, followed by the growth of the ZIF-67 shell membrane. The ZIF-67 was synthesized from solutions A and B as follow: Solution A: $0.0167 \mathrm{~mol}$ 2-methylimidazole dissolved in $15 \mathrm{ml}$ distilled water and Solution B: $0.00167 \mathrm{~mol}$ cobalt acetate dissolved in $15 \mathrm{ml}$ deionized water. The $\mathrm{Pt} / \mathrm{Al}_{2} \mathrm{O}_{3}$ core catalyst was immersed in the solution $\mathrm{A}$ for 5 minutes, then immersed in solution B for 5 minutes and then immersed in solution A for 5 minutes again. This procedure was repeated 5 times, then dried in air at $80{ }^{\circ} \mathrm{C}$ for $12 \mathrm{~h}$; the resulted product will be denoted as $\mathrm{Pt} / \mathrm{Al}_{2} \mathrm{O}_{3} @ \mathrm{ZIF}-67$ core-shell catalyst. Two samples with a thickness of the ZIF-67 shell membrane of 5 and $10 \mathrm{~nm}$ were prepared by controlling the number of immersion periods in solution $\mathrm{A}$ and $\mathrm{B}$, and these samples will be named Pt/ $\mathrm{Al}_{2} \mathrm{O}_{3} @ \mathrm{ZIF}-67-5$ and Pt/ $\mathrm{Al}_{2} \mathrm{O}_{3} @ \mathrm{ZIF}-67-10$, respectively.

\subsection{Characterization}

The Pt content in the sample was determined by inductively coupled plasmaatomic emission spectroscopy (ICP-AES). Before detection, $10 \mathrm{mg} \mathrm{Pt} / \mathrm{Al}_{2} \mathrm{O}_{3}$ sample powder was soaked in $20 \mathrm{ml}$ aqua regia for $70 \mathrm{~h}$. After $\mathrm{Pt} / \mathrm{Al}_{2} \mathrm{O}_{3}$ sample was completely 
dissolved, the solution was evaporated to $5 \mathrm{ml}$ at $80{ }^{\circ} \mathrm{C}$, transferred into $250 \mathrm{ml}$ volumetric flask, and diluted to the mark with distilled water. The noble metal $\mathrm{Pt}$ dispersion was measured by $\mathrm{H}_{2}$ chemisorption carried out on a Micromeritics AutoChem $2950 \mathrm{HP}$ Chemisorption Analyzer. The catalyst was reduced at $350{ }^{\circ} \mathrm{C}$ for $4 \mathrm{~h}$ and then under vacuum for $12 \mathrm{~h}$. The chemisorption of hydrogen was performed at $180{ }^{\circ} \mathrm{C}$ and $1 \mathrm{MPa}$. The number of Pt atoms on the surface of the $\mathrm{Al}_{2} \mathrm{O}_{3}$ was estimated by the number of $\mathrm{H}_{2}$ molecules adsorbed (i.e. $\mathrm{H}_{2}: \mathrm{Pt}=1: 2$ ). X-ray diffraction $(\mathrm{XRD})$ patterns were measured using a PANalytical X'Pert PRO diffractometer with $\mathrm{Cu} \mathrm{K} \alpha$ monochromatized radiation $\left(\lambda=1.54 \mathrm{~A}^{\circ}\right)$ operated at $45 \mathrm{kV}$ and $40 \mathrm{~mA}$, scan rate of $8^{\circ}$ $\min ^{-1}$ in $10-75^{\circ} 2 \theta$ range. A scanning electron microscope (SEM) with energy dispersive spectroscopy (EDS) was applied to analyze the core-shell catalyst (SEM, HITACHI, S4800). The spherical sample $\left(\mathrm{Pt} / \mathrm{Al}_{2} \mathrm{O}_{3} @ \mathrm{ZIF}-67\right)$ was washed under sonication for 20 minutes and dried at $120^{\circ} \mathrm{C}$ for $2 \mathrm{~h}$, then it was cut in half from the middle. The two obtained hemisphere slices were glued to the sample stage for measurement by SEM (one cross-section up and another cross-section down). TEM images were measured with a JEM-2100 (JEOL Co. Japan) instrument at an accelerating voltage of $200 \mathrm{kV}$. In order to the size distribution of Pt particles in the $\mathrm{Pt} / \mathrm{Al}_{2} \mathrm{O}_{3}$ catalyst, 10 representative microphotographs with more than $150 \mathrm{Pt}$ particles were determined as the average of two diameters of each particle. The porosity of samples was measured by nitrogen adsorption/desorption at $77 \mathrm{~K}$ using an ASAP 2020 Micromeritics instrument. The temperature programmed reduction (TPR) were applied to measure the reduction temperature of the catalyst $(100 \mathrm{mg})$ in a quartz gas flow reactor $\left(25-700{ }^{\circ} \mathrm{C}\right)$, with a heating rate of $10{ }^{\circ} \mathrm{C} \mathrm{min}^{-1}$, under a stream of $10 \% \mathrm{v} / \mathrm{v} \mathrm{H}_{2}$ in $\mathrm{Ar}$ (total flow rate $=100 \mathrm{~mL} \mathrm{~min}^{-1}$ ) at atmospheric pressure with a ChemBET 3000 Chemisorption Analyzer (Quantachrome Instruments). Thermogravimetric analysis 
(TGA) of the samples was performed using a Netzch TG 209 instrument in a nitrogen atmosphere $\left(25-900^{\circ} \mathrm{C}\right.$ with a ramp of $\left.10 \mathrm{~K} \cdot \mathrm{min}^{-1}\right)$. The infrared spectra (IR) were measured with a NEXUS FT-IR using the KBr technique.

\subsection{Catalytic tests}

Hydrogenation reaction on the $\mathrm{Pt} / \mathrm{Al}_{2} \mathrm{O}_{3} @ \mathrm{ZIF}-67-5$ core-shell catalyst was carried out in a high-pressure fixed-bed reactor in the temperature range $100-200{ }^{\circ} \mathrm{C}$. The alkenes with different molecular size (hexene, cyclohexene, and cyclooctene) dissolved in heptane solution were used as feed. The catalyst volume was $2.5 \mathrm{ml}$, the reaction pressure was 1.0 MPa, the liquid hourly space velocity (LHSV) was $3.0 \mathrm{~h}^{-1}$, and the $\mathrm{H}_{2} /$ feed ratio was 320 (Vol.). Before reaction, the catalysts were subjected to hydrogen reduction for $6 \mathrm{~h}$ at $350{ }^{\circ} \mathrm{C}$. The performance of the $\mathrm{Pt} / \mathrm{Al}_{2} \mathrm{O}_{3} @ \mathrm{ZIF}-67-5$ core-shell catalyst in the hydrogenation reaction was monitored by collecting liquid samples after $6 \mathrm{~h}$. The samples were analyzed by gas chromatography using an Agilent 7890N PONA GC (capillary column WAX, $60 \mathrm{~m}$ ). Benzene is used as a reference substances, relative quantitative correction factor was calculated according to the following equation:

$$
f_{i}=\frac{\mathrm{n}_{i}}{\mathrm{n}_{s}} \times \frac{\mathrm{A}_{s}}{\mathrm{~A}_{i}}
$$

where $f_{\mathrm{i}}$ is the relative quantitative correction factor of $\mathrm{i}, \mathrm{n}_{i}$ and $\mathrm{n}_{s}$ are the molar amount of $\mathrm{i}$ and benzene, $\mathrm{A}_{i}$ and $\mathrm{A}_{s}$ are the peak area of $\mathrm{i}$ and benzene, respectively.

The molar ratio and hydrogenation conversion were calculated according to the following equations:

$$
\begin{gathered}
\mathrm{M}_{i}=\frac{f_{i} \mathrm{~A}_{i}}{\sum_{i=1}^{n} f_{i} A_{i}} \times 100 \% \\
X_{i}=\frac{\mathrm{M}_{i}^{\text {Feed }}-\mathrm{M}_{i}^{\text {Product }}}{\mathrm{M}_{i}^{\text {Feed }}} \times 100 \%
\end{gathered}
$$

where $\mathrm{M}_{i}$ and $\mathrm{X}_{i}$ are the molar ratio and conversion of $\mathrm{i}, \mathrm{M}_{i}^{\text {Feed }}$ and $\mathrm{M}_{i}^{\text {Product }}$ are the 
molar ratio of $i$ in feed and product, respectively.

\section{Results and discussion}

\subsection{Properties of core-shell catalyst}

The XRD patterns of $\alpha-\mathrm{Al}_{2} \mathrm{O}_{3}, \mathrm{Pt} / \mathrm{Al}_{2} \mathrm{O}_{3}, \mathrm{Pt} / \mathrm{Al}_{2} \mathrm{O}_{3} @ \mathrm{ZIF}-67-5$ and pristine ZIF-67 are presented in Figure 1a. The XRD patterns of the $\mathrm{Pt} / \mathrm{Al}_{2} \mathrm{O}_{3}$ contain only the Bragg peaks corresponding to the $\alpha-\mathrm{Al}_{2} \mathrm{O}_{3}$; the absence of apparent Pt characteristic peaks might be due to the small particle size of the Pt nanoparticles and low Pt content $(0.52$ wt.\%) in the sample. For the Pt/ $\mathrm{Al}_{2} \mathrm{O}_{3} @ \mathrm{ZIF}-67-5$, all Bragg peaks match well with the crystalline $\alpha-\mathrm{Al}_{2} \mathrm{O}_{3}$ and ZIF-67 $\left(7.44,12.74,18.23{ }^{\circ} 2 \theta\right)$, indicating that the $\mathrm{Pt} / \mathrm{Al}_{2} \mathrm{O}_{3}$ core was successfully coated by the ZIF-67 shell. Figure 1(b, c) shows the scanning electron microscopy (SEM) images of the $\mathrm{Pt} / \mathrm{Al}_{2} \mathrm{O}_{3} @ \mathrm{ZIF}-67-5$. As shown, the $\mathrm{Pt} / \mathrm{Al}_{2} \mathrm{O}_{3}$ core was covered with a compact ZIF-67 shell membrane, and no conspicuous cracks or other defects were visible in the SEM top view image (Figure 1b). From the crosssection image, the thickness of the ZIF-67 layer was estimated to be about $5 \mu \mathrm{m}$ (Figure 1c). The average shell thickness of the $\mathrm{Pt} / \mathrm{Al}_{2} \mathrm{O}_{3} @ \mathrm{ZIF}-67-10$ was $10 \mu \mathrm{m}$ (Figure $\mathrm{S} 1$ ). As shown in Figure 1(d, e), the Pt particles of PA catalyst were uniformly dispersed on the surface of $\mathrm{Al}_{2} \mathrm{O}_{3}$ and the average sizes of Pt particles were 1.3-1.6 nm (Figure 1f).

The energy dispersive X-ray spectroscopy (EDS) data of the $\mathrm{Pt} / \mathrm{Al}_{2} \mathrm{O}_{3}$ and the $\mathrm{Pt} / \mathrm{Al}_{2} \mathrm{O}_{3} @ \mathrm{ZIF}-67-5$ are presented in Figure 2. As shown in Figure 2a, the main elements in the surface of the $\mathrm{Pt} / \mathrm{Al}_{2} \mathrm{O}_{3}$ core are $\mathrm{Al}, \mathrm{O}$, and $\mathrm{Pt}$, whereas $\mathrm{C}, \mathrm{N}, \mathrm{O}, \mathrm{Co}$, and $\mathrm{Al}$ are detected on the surface of the $\mathrm{Pt} / \mathrm{Al}_{2} \mathrm{O}_{3} @ \mathrm{ZIF}-67-5$ (Figure 2b), which further demonstrate that the ZIF-67 shell membrane covered the $\mathrm{Pt} / \mathrm{Al}_{2} \mathrm{O}_{3}$ core. Moreover, the distribution of $\mathrm{Co}$ and $\mathrm{Pt}$ from the shell to the core along the cross-sectional view of the $\mathrm{Pt} / \mathrm{Al}_{2} \mathrm{O}_{3} @ \mathrm{ZIF}-67-5$ was detected by EDS (Figure 2c). The Pt was detected at a 
penetration depth of $5 \mu \mathrm{m}$ and reaches a maximum at $15 \mu \mathrm{m}$, which shows that the $\mathrm{Pt}$ was loaded on the core surface. The distribution of Co has the different trend, its concentration first increased slightly and then decreased to zero. These results indicate that the $\mathrm{Pt} / \mathrm{Al}_{2} \mathrm{O}_{3}$ core is completely coated by a well-intergrown ZIF-67 shell membrane.

Moreover, the porosity of the $\mathrm{Pt} / \mathrm{Al}_{2} \mathrm{O}_{3}, \mathrm{Pt} / \mathrm{Al}_{2} \mathrm{O}_{3} @ \mathrm{ZIF}-67-5$, and ZIF-67 were confirmed by recording the nitrogen adsorption/desorption isotherms at $77 \mathrm{~K}$ (Figure 3a). The ZIF-67 displayed type I isotherm with a steep increase in $\mathrm{N}_{2}$ uptake at a low relative pressure $\left(0.01 \mathrm{P} / \mathrm{P}_{0}\right)$, which indicates the high crystallinity of the microporous material; the pore-size distribution is presented in Figure S2. The Pt/ $\mathrm{Al}_{2} \mathrm{O}_{3} @ \mathrm{ZIF}-67-5$ possesses microporosity which is mainly due to the contribution from the ZIF-67 shell membrane. The Brunauer-Emmett-Teller (BET) surface area and pore volume of the $\mathrm{Pt} / \mathrm{Al}_{2} \mathrm{O}_{3} @ \mathrm{ZIF}-67-5$ increase in comparison to the $\mathrm{Pt} / \mathrm{Al}_{2} \mathrm{O}_{3}$, mainly owing to the presence of ZIF-67 shell (Table S1). The IR spectrum of Pt/Al $\mathrm{O}_{3} @ Z$ IF-67-5 contains the characteristic peaks of ZIF-67 (Figure 3b). The peak at $437 \mathrm{~cm}^{-1}$ was the characteristic peaks of the Co-N bond, and the vibration peaks of the imidazole ring appeared in the spectral region of $600-1500 \mathrm{~cm}^{-1}$, which is indicating the successfully coating of ZIF-67 on the $\mathrm{Pt}^{-} \mathrm{Al}_{2} \mathrm{O}_{3}$ core. The thermogravimetric curve of $\mathrm{Pt} / \mathrm{Al}_{2} \mathrm{O}_{3} @ \mathrm{ZIF}-67-5$ is showed in Figure 3c. The first weight loss bellow $200{ }^{\circ} \mathrm{C}(3$ wt.\%) is due to the removal of water, while the second weight loss $(2 \mathrm{wt} . \%)$ at $430{ }^{\circ} \mathrm{C}$ is caused by the collapse of ZIF-67 membrane which is in agreement with the pristine ZIF-67 (Figure S3). The Pt/ $\mathrm{Al}_{2} \mathrm{O}_{3}$ and $\mathrm{Pt} / \mathrm{Al}_{2} \mathrm{O}_{3} @ \mathrm{ZIF}-67-5$ core-shell catalysts were characterized by TPR (Figure 3d). Two strong peaks at $249^{\circ} \mathrm{C}$ and $417^{\circ} \mathrm{C}$ for $\mathrm{Pt} / \mathrm{Al}_{2} \mathrm{O}_{3}$ and $\mathrm{Pt} / \mathrm{Al}_{2} \mathrm{O}_{3} @ \mathrm{ZIF}-67-5$ were measured indicating the bimodal particle distribution of Pt oxide. The first peak at $249^{\circ} \mathrm{C}$ corresponds to the reduction of small Pt oxide 
particles to platinum metal $\left(\mathrm{Pt}^{0}\right)$. The large particles are more difficult to be reduced, thus giving a rise to the TPR peak at $417^{\circ} \mathrm{C}$. The intensity of the reduction peaks for $\mathrm{Pt}$ in the $\mathrm{Pt} / \mathrm{Al}_{2} \mathrm{O}_{3} @ \mathrm{ZIF}-67-5$ sample was lower than that in the pure $\mathrm{Pt} / \mathrm{Al}_{2} \mathrm{O}_{3}$, which is suggesting that some active sites were covered by the ZIF-67 shell membrane.

\section{2. $\mathrm{Pt} / \mathrm{Al}_{2} \mathrm{O}_{3} @ \mathrm{ZIF}-67$ core-shell catalyst: selective hydrogenation reaction}

The catalytic performance of $\mathrm{Al}_{2} \mathrm{O}_{3}$ support, pure ZIF-67, $\mathrm{Al}_{2} \mathrm{O}_{3} @ \mathrm{ZIF}-67-5$, $\mathrm{Pt} / \mathrm{Al}_{2} \mathrm{O}_{3}$, and $\mathrm{Pt} / \mathrm{Al}_{2} \mathrm{O}_{3} @ \mathrm{ZIF}-67-5$ catalysts was evaluated in a high-pressure fixed-bed reactor $\left(100-200{ }^{\circ} \mathrm{C} ; 5\right.$ vol.\% hexene, 5 vol.\% cyclohexene, and 5 vol.\% cyclooctene dissolved in heptane solution were used as feed). The $\mathrm{Al}_{2} \mathrm{O}_{3}$ support, pure $\mathrm{ZIF}-67$, and $\mathrm{Al}_{2} \mathrm{O}_{3} @ \mathrm{ZIF}-67-5$ catalysts show no activity in hydrogenation reaction (Table $\mathrm{S} 2$ ). The conversion of hexene, cyclohexene, and cyclooctene increases over the catalysts with an increase of the temperature in Figure 4. The $\mathrm{Pt} / \mathrm{Al}_{2} \mathrm{O}_{3}$ catalyst displayed high activities in the hydrogenation of hexene, cyclohexene, and cyclooctene. The $\mathrm{Pt} / \mathrm{Al}_{2} \mathrm{O}_{3} @ \mathrm{ZIF}-67-5$ catalyst exhibits high hydrogenation selectivity. The conversion of hexene could reach $100 \%$ at $200{ }^{\circ} \mathrm{C}$, however, the conversion of cyclohexene and cyclooctene was significantly lower with no more than $40 \%$ and $10 \%$, respectively. The results could be attributed to the molecular sieving function of the ZIF-67 shell membrane (the aperture size $0.34 \mathrm{~nm}$ ) covered on the $\mathrm{Pt} / \mathrm{Al}_{2} \mathrm{O}_{3}$ surface, which prevents the larger molecules from contacting the active $\mathrm{Pt} / \mathrm{Al}_{2} \mathrm{O}_{3}$ core. Hexene with a size 0.17 $\mathrm{nm}$ can pass freely through the shell and take part in the reaction. In contrary, cyclohexene $(0.42 \mathrm{~nm})$ and cyclooctene $(0.55 \mathrm{~nm})$ could not pass the ZIF-67 shell membrane and therefore cannot contact the active $\mathrm{Pt} / \mathrm{Al}_{2} \mathrm{O}_{3}$ core. Hence, the Pt/Al $\mathrm{O}_{3} @$ ZIF-67-5 catalyst showed higher hydrogenation activity for hexene and lower activity for cyclohexene and cyclooctene. However, a few cyclohexene and cyclooctene still penetrate the compact ZIF-67 shell membrane. It could be attributed 
to the flexibility of ZIF-67 lattice [38, 39], the rotation of the 2-methylimidazole ligand and the framework deformation resulted from the high temperature can increase the aperture size of ZIF-67 [40, 41]. Another reason could also be duo to small cracks occurred in the membrane at high temperature.

\subsection{Pt/Al $\mathrm{O}_{3} @ \mathrm{ZIF}-67$ core-shell catalyst: effect of reaction conditions on hydrogenation}

In order to evaluate the effect of the shell (membrane) thickness on the catalytic performance of the $\mathrm{Pt} / \mathrm{Al}_{2} \mathrm{O}_{3} @ \mathrm{ZIF}-67$ core-shell material, the selectivity test of samples with different shell thicknesses were carried out (5 vol.\% hexene, 5 vol.\% cyclohexene dissolved in heptane solution as feed at $180{ }^{\circ} \mathrm{C}$ ). As shown in Figure 5, the conversion of cyclohexene over the Pt/Al ${ }_{2} \mathrm{O}_{3} @ Z$ ZIF-67-10 catalyst was lower than that over the $\mathrm{Pt} / \mathrm{Al}_{2} \mathrm{O}_{3} @ \mathrm{ZIF}-67-5$. The shape selectivity of the catalyst is significantly improved with the increase of the shell thickness. However, the restriction for diffusion of hexene increased with the increase of shell thickness, and therefore the conversion of hexene decreased. The conversion of all reactants remained almost unchanged with the increase of the reaction pressure (see Figure 6). The increase in hydrogen pressure should be beneficial for the hydrogenation reaction, but the cyclohexene and cyclooctene cannot easily contact the active component due to the restrictions of ZIF-67 shell membrane, thus the conversion does not increase significantly. The effect of the LHSV on the hydrogenation reaction was showed in Figure 7. The conversions of all reactants decreased as the LHSV increases. The contact time between the reactants and catalyst reduced with the increase of LHSV. The optimum LHSV is $3 \mathrm{~h}^{-1}$, and the $\mathrm{Pt} / \mathrm{Al}_{2} \mathrm{O}_{3} @ \mathrm{ZIF}-67-5$ shows very high selectivity and $100 \%$ conversion in hydrogenation of hexene. The effect of LHSV on hexene hydrogenation reaction over $\mathrm{Pt} / \mathrm{Al}_{2} \mathrm{O}_{3} @ \mathrm{ZIF}-67-5$ is large than over $\mathrm{Pt} / \mathrm{Al}_{2} \mathrm{O}_{3}$ catalyst (Figure $\mathrm{S} 4$ ), indicating that the 
resistance that reactant to $\mathrm{Pt}$ active sites is increased duo to ZIF-67 shell. The shell formation has an important impact on mass transfer.

\section{4. $\mathrm{Pt} / \mathrm{Al}_{2} \mathrm{O}_{3} @ \mathrm{ZIF}-67$ core-shell catalyst: stability and long term performance}

The stability test for the Pt/ $\mathrm{Al}_{2} \mathrm{O}_{3} @ \mathrm{ZIF}-67-5$ core-shell catalyst was performed using hexene and cyclooctene as feedstock at $180{ }^{\circ} \mathrm{C}$. As shown in Figure S5, after 70 $\mathrm{h}$, the conversion of hexene remained $100 \%$, but the activity for cyclooctene was low; the conversion was no more than $10 \%$. This result confirms that the $\mathrm{Pt} / \mathrm{Al}_{2} \mathrm{O}_{3} @ \mathrm{ZIF}-67$ catalyst is stable, and therefore the $\mathrm{Pt} / \mathrm{Al}_{2} \mathrm{O}_{3} @ \mathrm{ZIF}-67-5$ catalyst was separated from the reaction system and reused under the same conditions in 4 subsequent cycles. The $\mathrm{Pt} / \mathrm{Al}_{2} \mathrm{O}_{3} @ \mathrm{ZIF}-67-5$ catalyst showed high activity for hydrogenation of hexene after four cycles (100\% conversion, Figure 8$)$. In addition, lower activity in hydrogenation of cyclooctene was maintained during the 4 subsequent cycles. The excellent performance of the catalyst is attributed to the integrity of ZIF-67 crystalline structure that protects the Pt from loss and leaching during the reaction. The XRD patterns of the $\mathrm{Pt} / \mathrm{Al}_{2} \mathrm{O}_{3} @ \mathrm{ZIF}-67-5$ after four cycles showed the peaks corresponding to the ZIF-67 structure (Figure S6), thus further proving the stability of the ZIF-67 shell membrane.

\subsection{Pt/Al $\mathrm{O}_{3} @ \mathrm{ZIF}$-67 core-shell catalyst: sulfur resistance performance}

Since noble metals are extremely sensitive to sulfur compounds, the presence of a trace of sulfur in the reactants will poison the platinum nanoparticles. Therefore, the catalyst antitoxic ability is very important for hydrogenation. We investigated the sulfur-resistant property of the $\mathrm{Pt} / \mathrm{Al}_{2} \mathrm{O}_{3} @ \mathrm{ZIF}-67-5$ catalyst, by adding 200 ppm dibenzothiophene to the hexene hydrogenation reaction system. As shown in Figure 9, the Pt/Al $\mathrm{O}_{3} @ \mathrm{ZIF}-67-5$ core-shell catalyst showed a high activity for the hydrogenation reaction, the conversion of hexene maintained $100 \%$ over time. 
However, the bear $\mathrm{Pt} / \mathrm{Al}_{2} \mathrm{O}_{3}$ catalyst without ZIF-67 shell membrane showed a rapid loss of activity under the same conditions. After $7 \mathrm{~h}$, the conversion of hexene dramatically decreased from $100 \%$ to $15 \%$, which indicated that most Pt NPs were poisoned by dibenzothiophene. Based on the above results, it can be concluded that the ZIF-67 shell membrane fully eliminates the contact between the large sulfur-containing molecules and metal active sites $(\mathrm{Pt})$, demonstrating high sulfur resistance.

\section{Conclusion}

A new core-shell catalyst containing $\mathrm{Pt} / \mathrm{Al}_{2} \mathrm{O}_{3}$ core and ZIF-67 shell membrane was prepared. The Pt/Al $\mathrm{O}_{3} @ \mathrm{ZIF}-67$ core-shell catalyst showed excellent selectivity for small-sized alkenes hydrogenation, high anti-poisoning effect in the presence of 200ppm sulfur compounds, and outstanding stability after multi cycle analysis. This study offers a new strategy for design of protective membrane for noble metals in catalysts, and more specifically on the design of core-shell materials with long term stability towards sulfur compounds.

\section{Acknowledgments}

The authors are grateful for National Natural Science Foundation of China [Grant No. 21673291, 21201180, 21776314], Shandong Provincial Natural Science Foundation [ZR2012BQ014], the Fundamental Research Funds for the Central Universities [No. 18CX05018A, 15CX05012A], Qingdao Application of Basic Research Projects [No.14-2-4-36-jch], the Innovative Engineering Projects (YCX2018024), Fondation

Franco-Chinoise pour la Science et ses Applications club, and the Sino-French LIA "Zeolite".

\section{Reference}


[1] C. Amorim, G. Yuan, P. M. Patterson, A. K. Mark, J. Catal. 234 (2005) 268-281

[2] J. Guerra, M. A. Herrero, Nanoscale 2 (2010) 1390-1400.

[3] R. G. Zhang, H. Y. Liu, B. J. Wang, L. X. Ling, Appl. Catal. B. 126 (2012) 108120.

[4] V. Polshettiwar, C. Len, A. Fihri, Coord. Chem. Rev. 253 (2009) 2599-2626.

[5] K. Okumura, K. Nota, K. Yoshida, M. Niwa, J. Catal. 231 (2005) 245-253.

[6] S. Mandal, D. Roy, R. V. Chaudhari, M. Sastry, Chem. Mater. 16 (2004) 37143724.

[7] J. M. Thomas, B. F. Johnson, R. Raja, G. Sanker, P. A. Midgley, Acc. Chem. Res. 36 (2003) 20-30.

[8] A. Balanta, C. Godard, C. Claver, Chem. Soc. Rev. 40 (2011) 4973-4985.

[9] R. Martin, S. L. Buchwald, Coord. Chem. Rev. 41 (2008) 1461-1473.

[10] A. V. Gaikwad, A. Holuigue, M. B. Thathagar, J. T. Elshof, G. Rothenberg, Chem.-Eur. J. 13 (2007) 6908-6913.

[11] J. N. Park, A. J. Forman, W. Tang, J. H. Cheng, Y. S. Hu, H. F. Lin, E. W. McFarlad, Small 4 (2008) 1694-1697.

[12] M. Besson, P. Gallezot, Catal. Today 81 (2003) 547-559.

[13] C. Song, Chem. Tech. 29 (1999) 26-30.

[14] H. Chen, H. Yang, Y. Briker, C. Fairbridge, O. Omotoso, L. Ding, Y. Zheng, Z.

Ring, Catal. Today. 125 (2007) 256-262.

[15] Y. Sun, R. Prins, Angew. Chem. Int. Ed. 47 (2008) 8478-8481.

[16] W. Fu, L. Zhang, T. Tang, Q. Ke, S. Wang, J. Hu, G. Fang, J. Li, F. Xiao, J. Am. Chem. Soc. 133 (2011) 15346-15349.

[17] T. Tang, L. Zhang, W. Fu, Y. Ma, J. Xu, J. Jiang, G. Fang, F. Xiao, J. Am.

Chem. Soc. 135 (2013) 11437-11440.

[18] S. Goel, S. Zones, E. Iglesia, J. Am. Chem. Soc. 136 (2014) 15280-15290.

[19] T. Otto, S. Zones, E. Iglesia, J. Catal. 339 (2016) 195-208.

[20] J. Gu, Z. Zhang, P. Hu, L. Ding, N. Xue, L. Peng, X. Guo, M. Lin, W. Ding, ACS Catal. 5 (2015) 6893-6901.

[21] K.T. Højholt, S.K. Laursen, C.H. Christensen, Top. Catal. 54 (2011) 1026-1033

[22] L. Yin, J. Liebscher, Chem. Rev. 107 (2007) 133-173.

[23] A. Roucoux, J. Schulz, H. Patin, Chem. Rev. 102 (2002) 3757-3778.

[24] A. T. Bell, Science, 299 (2003) 1688-1691.

[25] F. Zaera, Chem. Soc. Rev. 42 (2013) 2746-2762.

[26] S. Liu, M. Y. Han, Chem. Asian J. 5 (2010) 36-45.

[27] D. K. Yi, S. T. Selvan, S. S. Lee, G. C. Papaefthymiou, D. Kundaliya, J. Y. Ying, J. Am. Chem. Soc. 127 (2005) 4990-4991.

[28] X. Sun, Y. Li, Angew. Chem. Int. Ed. 43 (2004) 597-601.

[29] Y. Deng, D. Qi, C. Deng, X. Zhang, D. Zhao, J. Am. Chem. Soc. 130 (2008) 2829.

[30] S. Alayoglu, A. U. Nilekar, M. Mavrikakis, B. Eichhorn, Nature Mater. 7 (2008) 333.

[31] L. F. Cui, Y. Yang, C. M. Hsu, Y. Cui, Nano Lett. 9 (2009) 3370-3374.

[32] C. Wang, D. Liu, W. Lin, J. Am. Chem. Soc. 135 (2013) 13222-13234.

[33] H. R. Moon, D. W. Lim, M. P. Suh, Chem. Soc. Rev. 42 (2013) 1807-1824.

[34] K. S. Park, Z. Ni, A. P. Cüt, J. Y. Choi, R. Huang, F. J. UribeRomo, H. K. Chae, M. OÏKeeffe, O. M. Yaghi, Proc. Natl. Acad. Sci. 103 (2006) 10186-91.

[35] X. C. Huang, Y. Y. Lin, J. P. Zhang, X. M. Chen, Angew. Chem. Int. Ed. 13 (2007) 4146-4154. 
[36] C. H. Kuo, Y. Tang, L. Y. Chou, B. T. Sneed, C. N. Brodsky, Z. Zhao, C. K. Tsung, J. Am. Chem. Soc. 134 (2012) 14345-14348.

[37] S. Sorribas, B. Zornoza, C. Tellez, J. Coronas, Chem. Commun. 48 (2012) 93889390.

[38] X. F. Zhang, Y. G. Liu, L. Y. Kong, H. O. Liu, J. S. Qiu, W. Han, L. T. Weng, K. L. Yeung, W. D. Zhu, J. Mater. Chem. A 1 (2013) 10635-10638.

[39] X. F. Zhang, Y. G. Liu, S. H. Li, L. Y. Kong, H. O. Liu, Y. S. Li, W. Han, K. L. Yeung, W. D. Zhu, W. S. Yang, J. S. Qiu, Chem. Mater. 26 (2014) 1975-1981.

[40] D. Fairen-Jimenez, S. A. Moggach, M. T. Wharmby, P. A. Wright, S. Parsons, T. Duren, J. Am. Chem. Soc. 133 (2011) 8900-8902.

[41] G. Kumari, K. Jayaramulu, T. K. Maji, C. Narayana, J. Phys. Chem. A. 117 (2013) 11006-11012.

\section{Scheme}




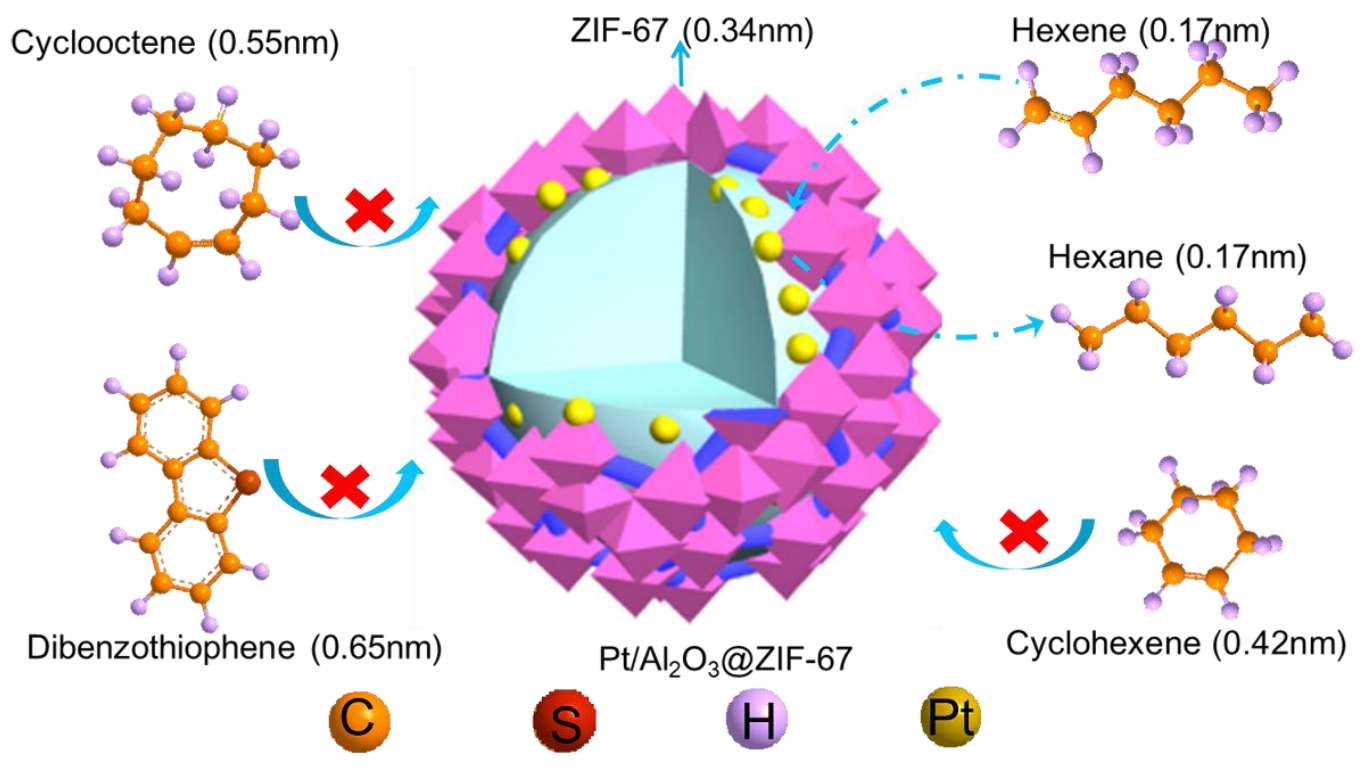

Scheme 1. A sulfur-tolerant Pt/ $\mathrm{Al}_{2} \mathrm{O}_{3} @ \mathrm{ZIF}-67$ core-shell catalyst for the selective hydrogenation of alkenes. 


\section{Figure Captions}
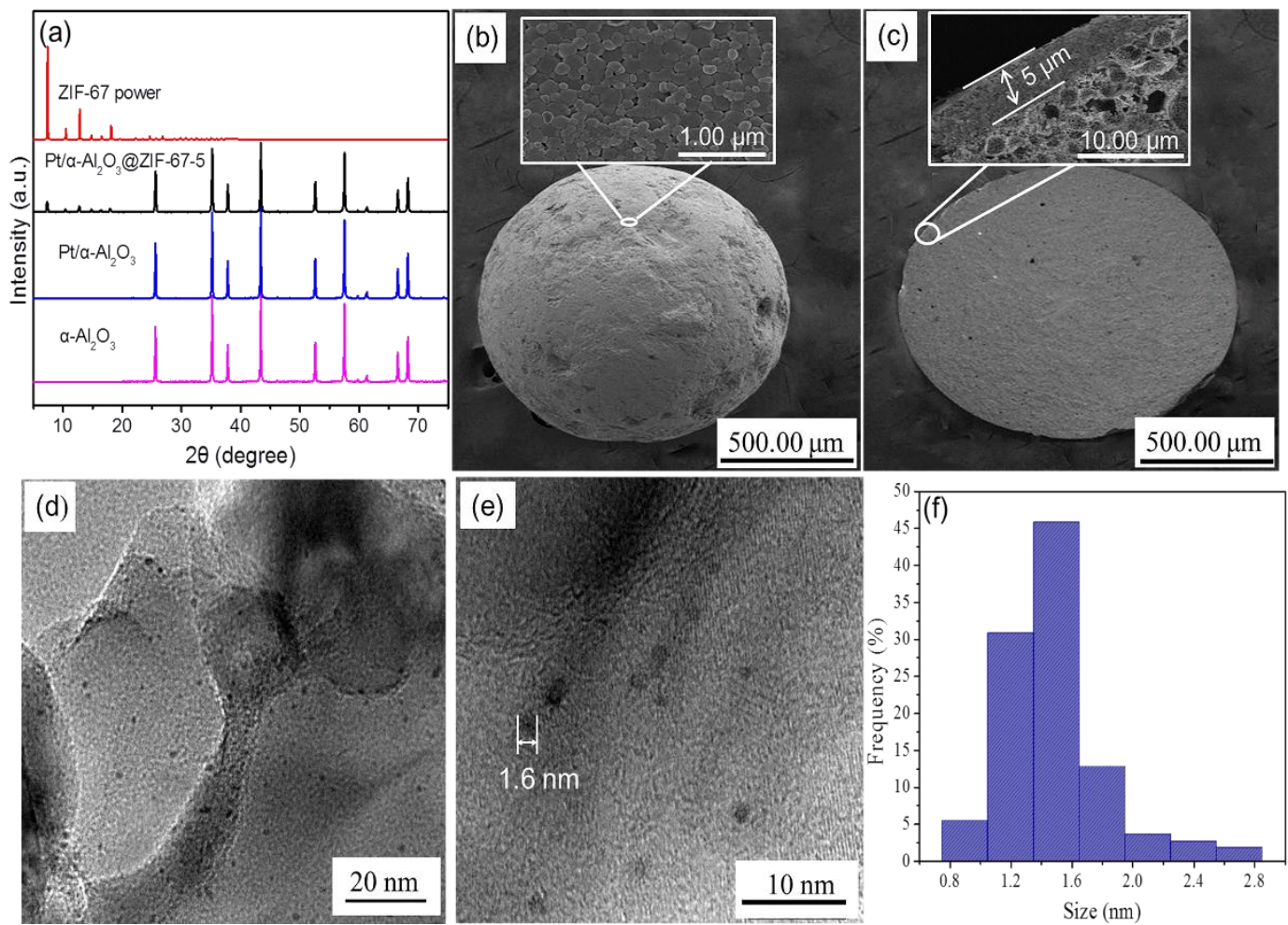

Figure 1. XRD patterns (a) of $\alpha-\mathrm{Al}_{2} \mathrm{O}_{3}, \mathrm{Pt} / \mathrm{Al}_{2} \mathrm{O}_{3}, \mathrm{Pt} / \mathrm{Al}_{2} \mathrm{O}_{3} @ \mathrm{ZIF}-67-5$, and pure ZIF67; SEM top view (b), and SEM cross-section image (c) of Pt/Al ${ }_{2} \mathrm{O}_{3} @ Z I F-67-5$ coreshell; TEM images of $\mathrm{Pt} / \mathrm{Al}_{2} \mathrm{O}_{3}$ catalyst (d, e), the particle size distribution of $\mathrm{Pt}$ in the $\mathrm{Pt} / \mathrm{Al}_{2} \mathrm{O}_{3}$ catalyst (f). 

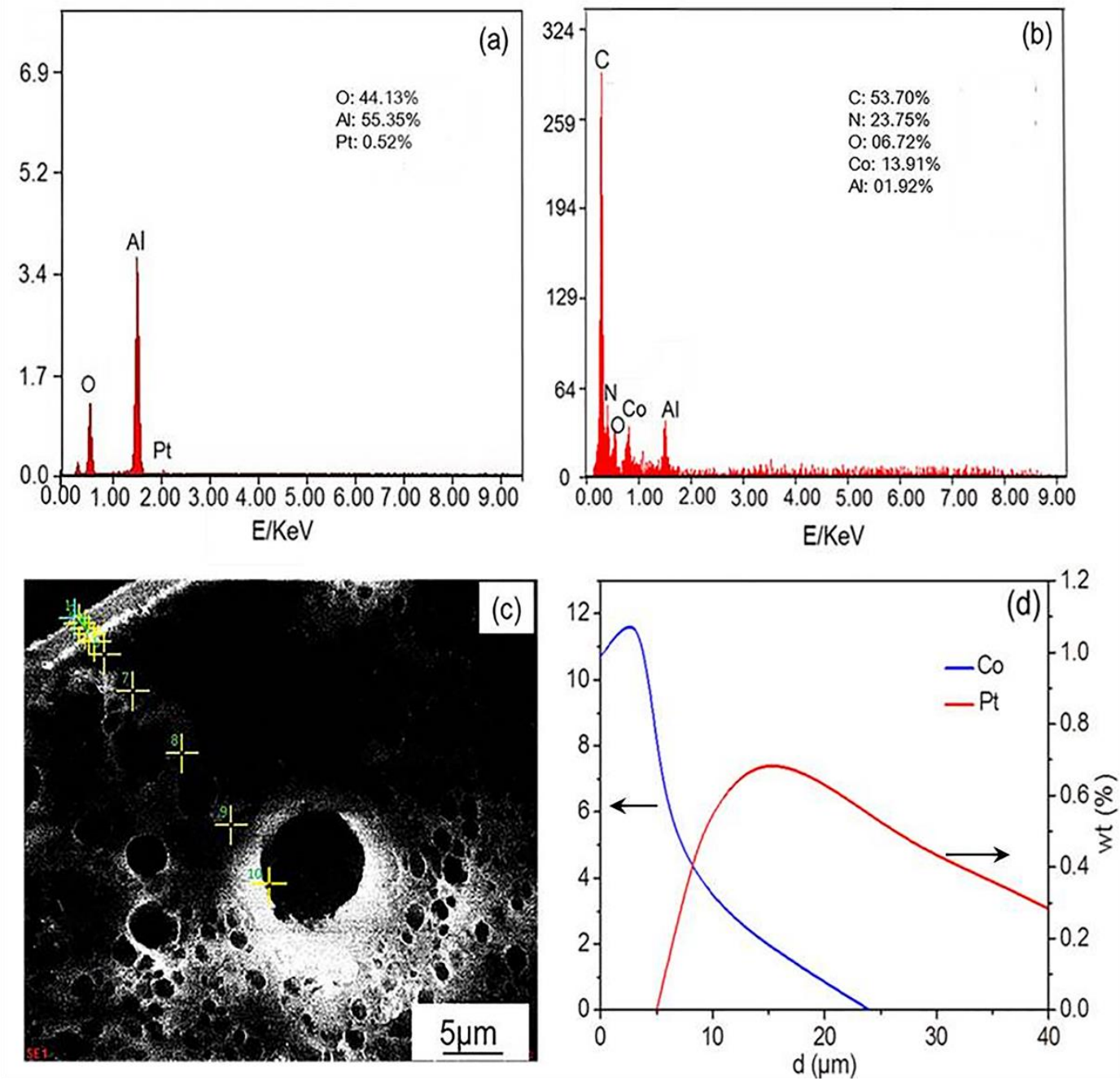

Figure 2. EDS analysis of $\mathrm{Pt} / \mathrm{Al}_{2} \mathrm{O}_{3}$ (a) and $\mathrm{Pt} / \mathrm{Al}_{2} \mathrm{O}_{3} @ \mathrm{ZIF}-67-5$ (b), SEM crosssection view of $\mathrm{Pt} / \mathrm{Al}_{2} \mathrm{O}_{3} @ \mathrm{ZIF}-67-5$ (c), and the corresponding chemical composition along the $\mathrm{Pt} / \mathrm{Al}_{2} \mathrm{O}_{3} @ \mathrm{ZIF}-67-5$ core-shell catalyst with a penetration depth of $40 \mu \mathrm{m}$ (d). 

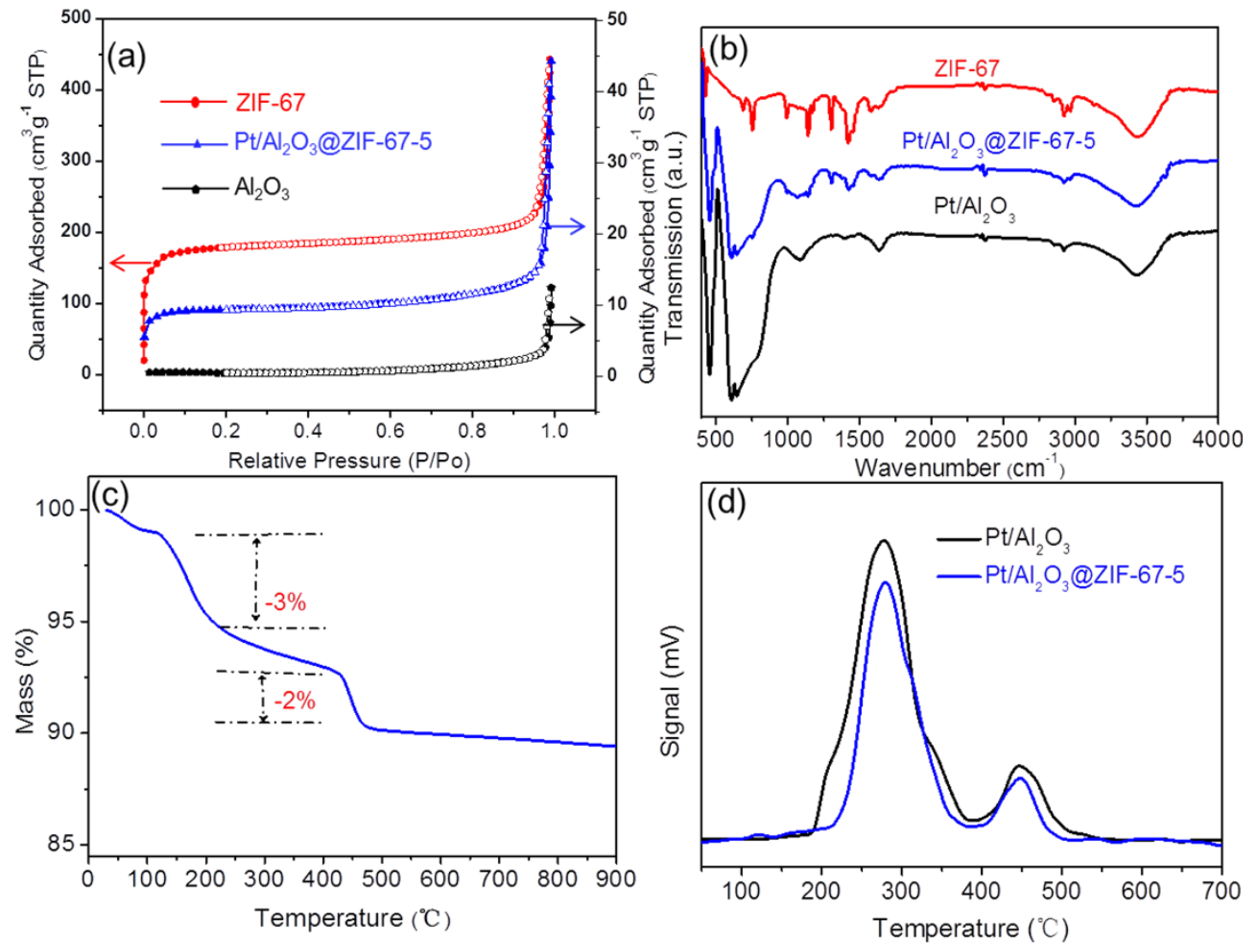

Figure 3. $\mathrm{N}_{2}$ adsorption-desorption isotherms (a), FT-IR spectra (b) of ZIF-67, Pt/ $\mathrm{Al}_{2} \mathrm{O}_{3}$, and Pt/Al $\mathrm{Al}_{2} \mathrm{O}_{3} @ \mathrm{ZIF}-67-5$; TG curve of Pt/ $\mathrm{Al}_{2} \mathrm{O}_{3} @ \mathrm{ZIF}-67-5$ (c), and TPR profiles of $\mathrm{Pt} / \mathrm{Al}_{2} \mathrm{O}_{3}$ and $\mathrm{Pt} / \mathrm{Al}_{2} \mathrm{O}_{3} @ \mathrm{ZIF}-67-5$ (d). 


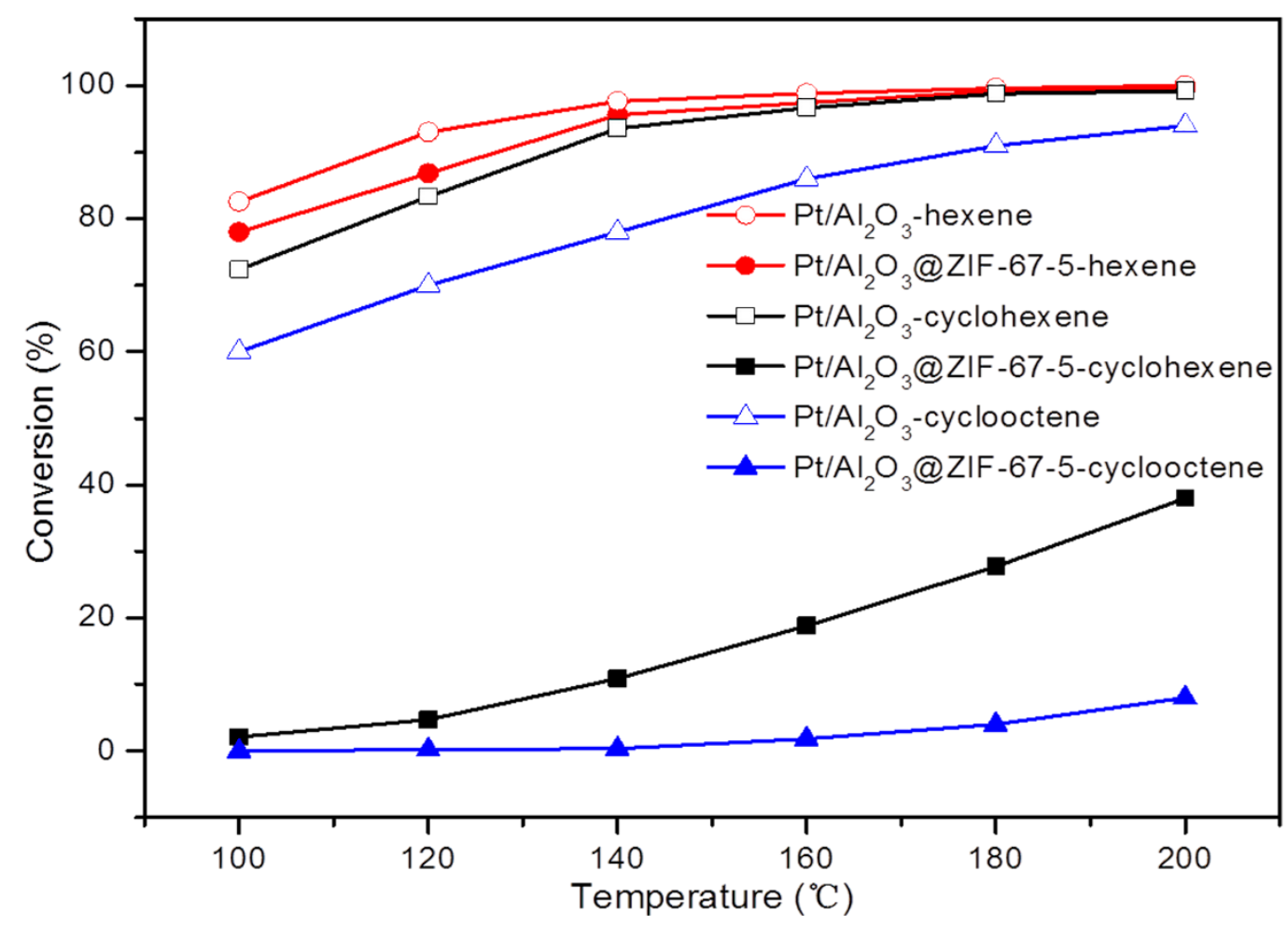

Figure 4. Size-selective hydrogenations of hexane (red), cyclohexene (black), and cyclooctene (blue) over Pt/ $\mathrm{Al}_{2} \mathrm{O}_{3}$ (full symbols) and Pt/Al ${ }_{2} \mathrm{O}_{3} @ Z$ ZIF-67-5 (open symbols) catalysts. 


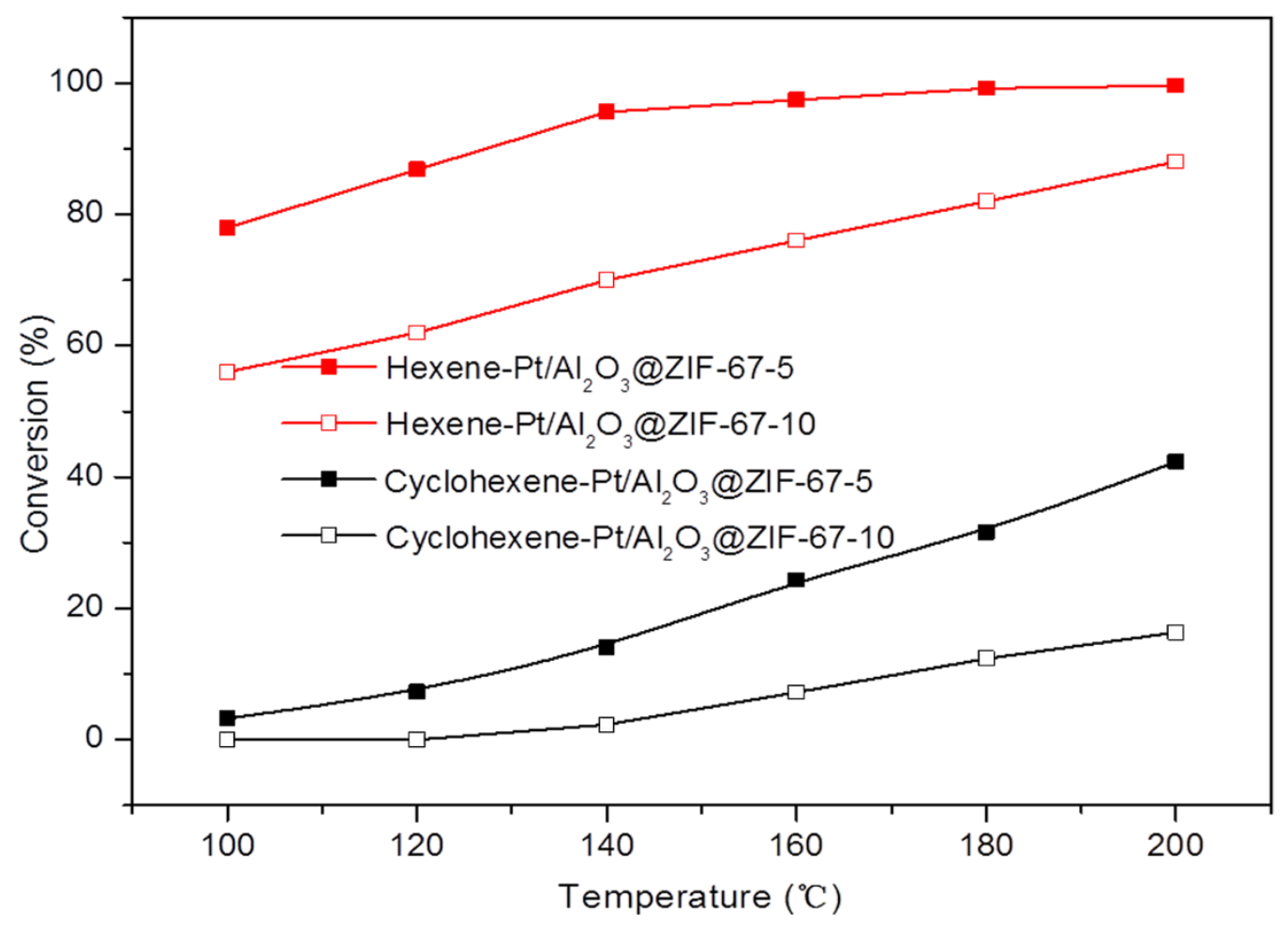

Figure 5. Size-selective hydrogenations of hexene (red) and cyclohexene (black) over Pt/Al $\mathrm{O}_{3} @ \mathrm{ZIF}-67-5$ (full symbols) and Pt/ $\mathrm{Al}_{2} \mathrm{O}_{3} @ \mathrm{ZIF}-67-10$ (open symbols). 


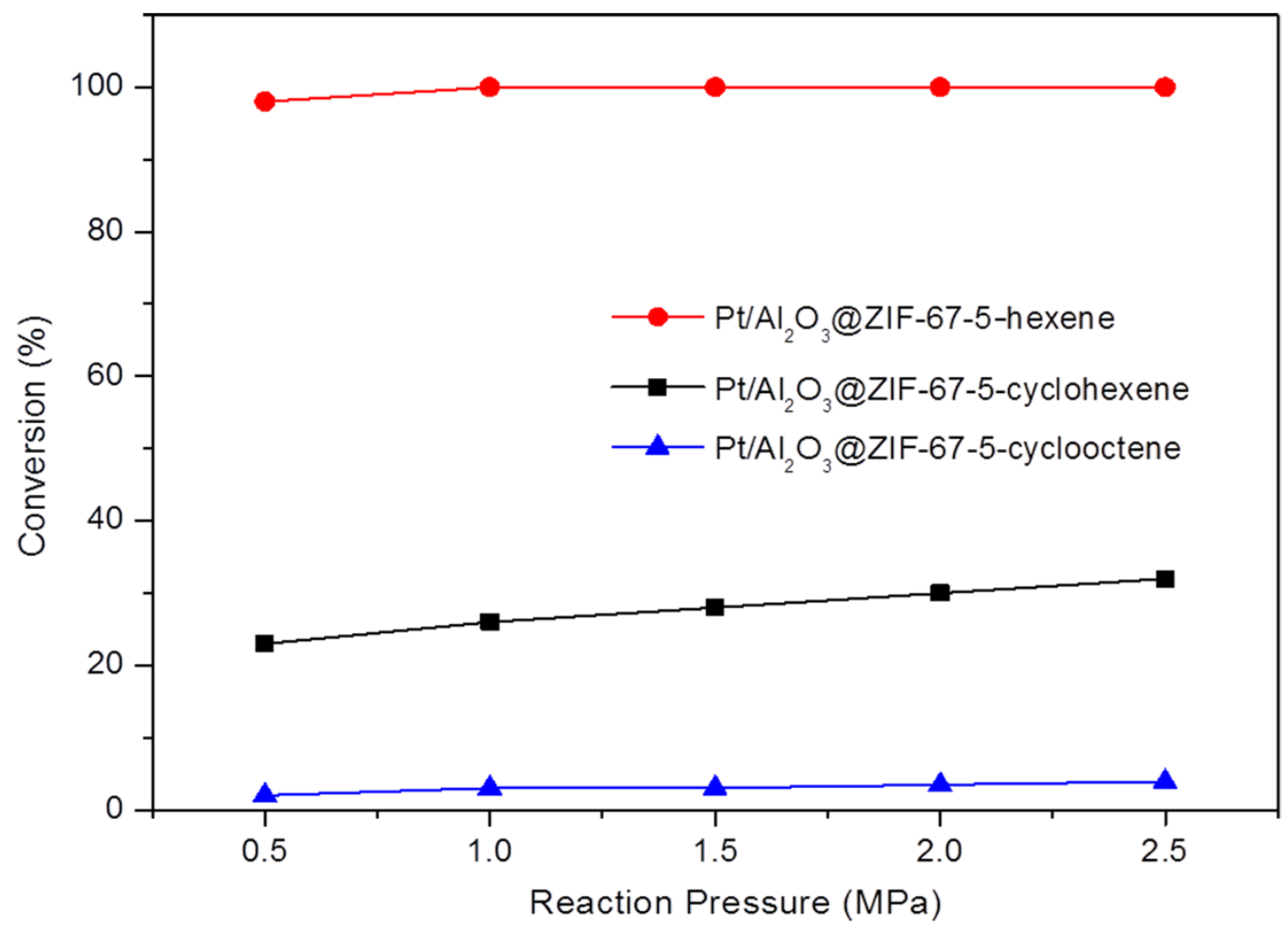

Figure 6. Conversion of hexane (red), cyclohexane (black) and cyclooctene (blue) over the $\mathrm{Pt} / \mathrm{Al}_{2} \mathrm{O}_{3} @ \mathrm{ZIF}-67-5$ core-shell catalyst at different reaction pressure. 


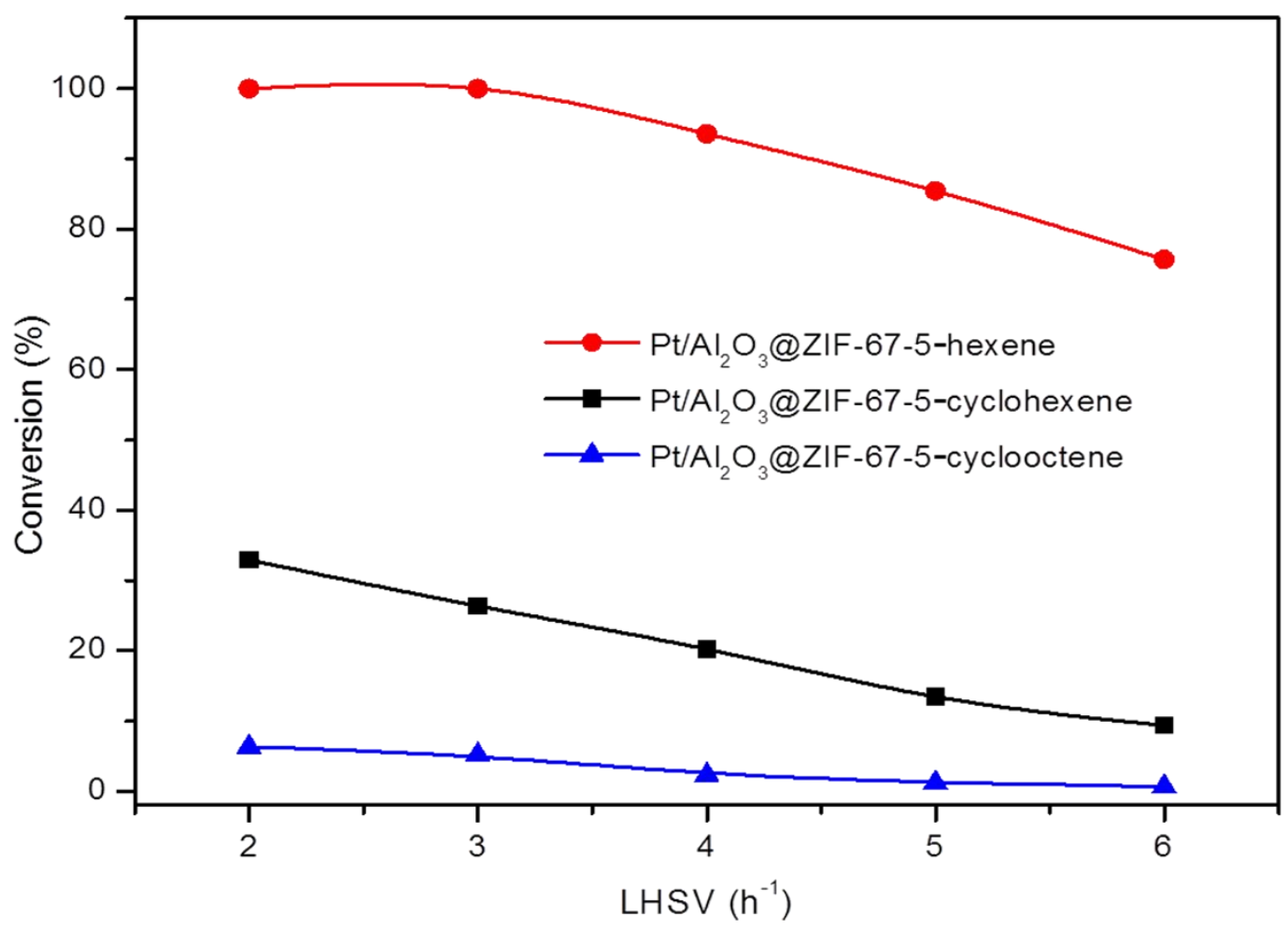

Figure 7. Conversion of hexane (red), cyclohexane (black) and cyclooctene (blue) over the $\mathrm{Pt} / \mathrm{Al}_{2} \mathrm{O}_{3} @ Z$ ZIF-67-5 core-shell catalyst at different liquid hourly space velocity (LHSV). 


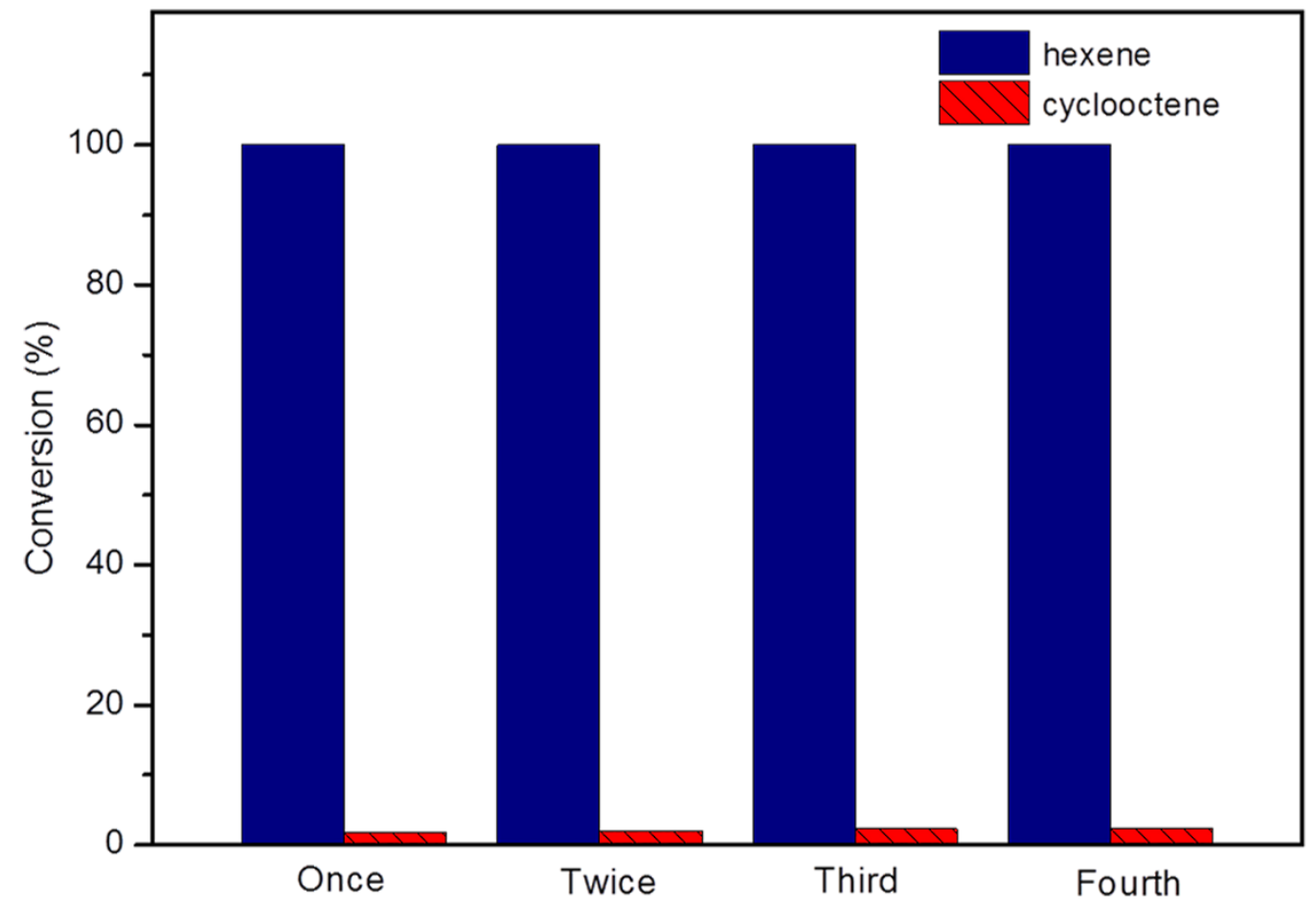

Figure 8. Long term stability of the $\mathrm{Pt} / \mathrm{Al}_{2} \mathrm{O}_{3} @ \mathrm{Zif}-67-5$ core-shell catalyst for alkenes hydrogenation (hexane: blue, cyclooctene: red) in 4 subsequent cycles. 


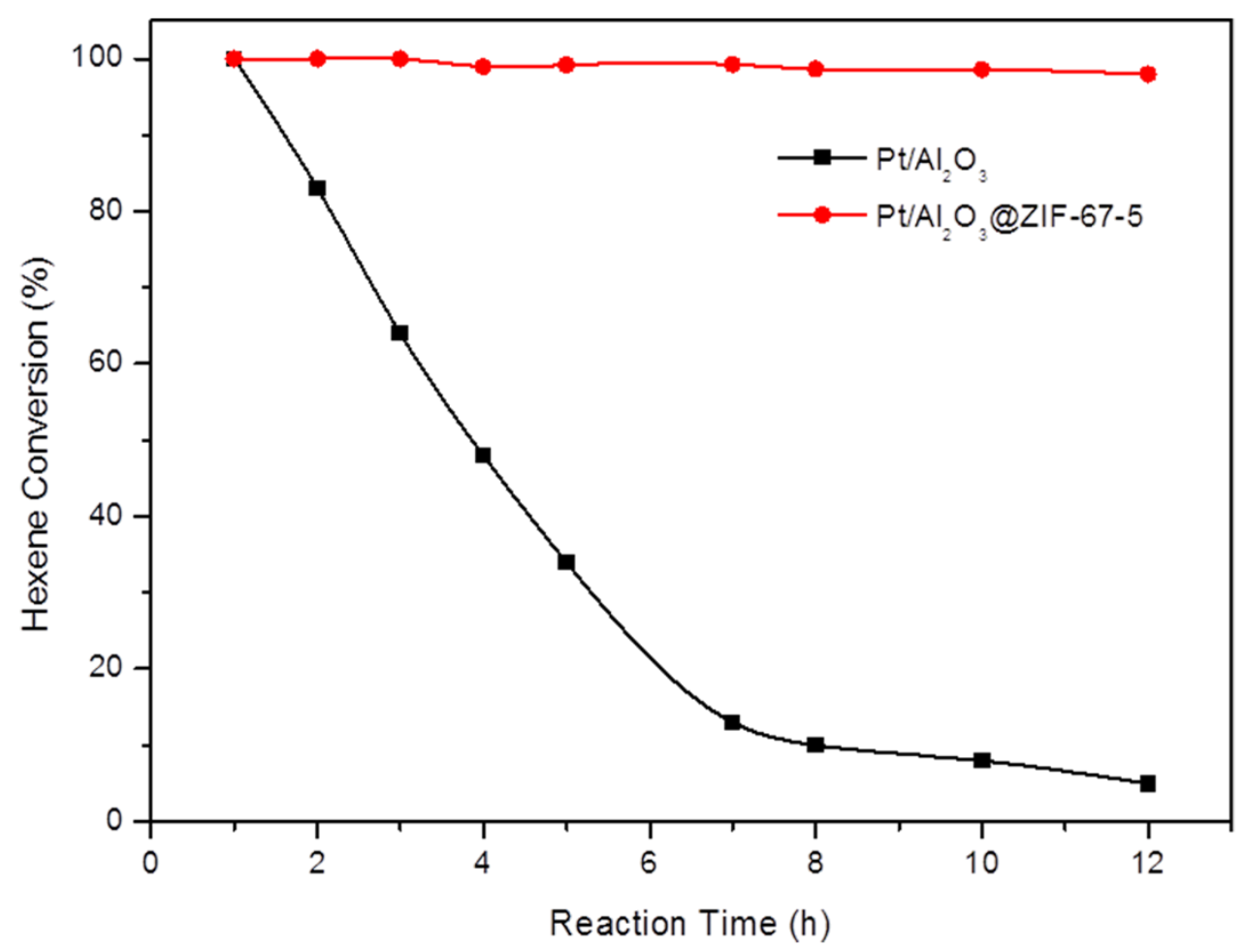

Figure 9. The sulfur-resistant properties of $\mathrm{Pt} / \mathrm{Al}_{2} \mathrm{O}_{3}$ (black) and $\mathrm{Pt} / \mathrm{Al}_{2} \mathrm{O}_{3} @ \mathrm{ZIF}-67-5$ (red) catalysts: hexane conversion as a function of time. 